\title{
Dating the Anthropocene in deep-sea sediments: how much carbon is
}

buried in the Irminger Basin?

\section{Marcos Fontelaa, Guillermo Francés ${ }^{b}$, Begoña Quintanac, María J. Álvarez- Fernández ${ }^{a}$, Miguel A. Nombela ${ }^{b}$, Irene Alejo ${ }^{b}$, María C. Pedrosac, Fiz F. Pérez ${ }^{a}$}

a Instituto de Investigaciones Marinas, IIM-CSIC, 36208 Vigo, Spain.

b Departamento de Geociencias Marinas y Ordenación del Territorio, Universidad de Vigo, Spain.

c Departamento de Física Fundamental, Universidad de Salamanca, Spain. Corresponding author: Marcos Fontela (mfontela@iim.csic.es)

\section{Abstract}

Evaluation of biogeochemical processes in Anthropocene deep-sea sediments require accurate dating techniques. Here we show the results of an approach using high resolution low level background gamma spectrometry with two simultaneous hyper-pure germanium (HPGe) detectors. The quantitative role of the deepest zones (>3000 m depth) of the Irminger Basin (Subpolar North Atlantic Ocean) as a carbon sink during the Anthropocene is evaluated combining a chronology based in the natural radionuclide ${ }^{210} \mathrm{~Pb}$ with sedimentological analysis and elemental composition. The average sedimentation rate of the central Irminger is $1.28 \pm 0.18 \mathrm{~mm} \cdot \mathrm{yr}^{-1}$, with a mean weighted flux to the sediment for inorganic and organic carbon of $46 \pm 15 \mathrm{~g} \cdot$ Cinorg $_{\text {ing }} \cdot \mathrm{m}^{-2} \cdot \mathrm{yr}^{-1}$ and $8 \pm 1$ $\mathrm{g} \cdot \mathrm{C}_{\text {org }} \cdot \mathrm{m}^{-2} \cdot \mathrm{yr}^{-1}$. The biogenic fraction of the mass flux is increased since the $X \mathrm{X}^{\text {th }}$ century. The contribution of the deepest zones of the Irminger Basin to the Anthropocene carbon sequestration in the North Atlantic Ocean is considerable at basin-scale.

Keywords: Deep-sea sedimentation rate, Subpolar North Atlantic, Irminger Basin, Carbon sink, Geochronology, Anthropocene.

\section{Introduction}

A new geological epoch has been proposed: the Anthropocene (Crutzen and Stoermer, 2000). It is based in the scientific community consensus that humankind has already alters the Earth-system and has become a global geological force by its own (Steffen et al., 2011; Waters et al., 2016). However, there is no global consensus to mark the onset 
of the Anthropocene, but the option to set it the lower boundary at the mid-20th century 33 is gaining strength (Steffen et al., 2016; Waters et al., 2016; Williams et al., 2016). Detection of the Anthropocene is relatively easier in coastal and estuarine areas with greater anthropogenic pressure (Álvarez-Iglesias et al., 2007; Leorri et al., 2014; Irabien et al., 2015; Álvarez-Vázquez et al., 2016) than in remote deep-sea basins, where the relatively low sedimentation rates require precise dating techniques to identify the onset. The combination of an accurate Anthropocene detection with sedimentological analysis and elemental composition allows the evaluation of fluxes to the sediment (ÁlvarezVázquez et al., 2016), and can give an insight to comprehend recent biogeochemical processes. In the current status of knowledge of biogeochemical cycles (carbon cycle included), the magnitude exported from the water column to deep-sea sediments remains poorly constrained (Burd et al., 2010; Heinze et al., 2015; Honjo et al., 2008).

Here we show the results of a high-resolution radiochronologic approach via gamma spectrometry applied to pelagic sediments of the central Irminger Basin (Subpolar North Atlantic). High-resolution deep-sea sediment chronologies are increasing in number, especially at zones of high sedimentation rate such as contourite deposits (Boessenkool et al., 2007; Moffa-Sánchez et al., 2014), but similar studies for recent pelagic sediments, as the one proposed here, are still scarce. For our study, we used a gamma spectrometry detector specifically designed to enhance the performance of chronologies in oceanic sediments (Quintana et al., 2017). The dating is based of ${ }^{210} \mathrm{~Pb}$, a natural geogenic radionuclide that enters the oceans mainly via atmospheric deposition and is one of the decay products of the ${ }^{238} \mathrm{U}$ series $\left(\mathrm{T}_{1 / 2}=22.23 \pm 0.12 \mathrm{yr}\right)(D D E P, 2017$; Mabit et al., 2014). The method can be applied to date sediments from the last 100-150 years, it is a nondestructive technique and gives information on all gamma emitters present in the sample $\left({ }^{226} \mathrm{Ra},{ }^{137} \mathrm{Cs},{ }^{241} \mathrm{Am} . ..\right)$. The detection of anthropogenic radionuclides ${ }^{137} \mathrm{Cs}$ and ${ }^{241} \mathrm{Am}$, with known dates of input can be used to validate the age model (Sanchez-Cabeza and Ruiz-Fernández, 2012).

The ${ }^{210} \mathrm{~Pb}$ dating model is based on two facts: the enrichment of ${ }^{210} \mathrm{~Pb}$ with respect to ${ }^{226} \mathrm{Ra}$ in aerosols and suspended particles in the atmosphere and the water column, which deposit in the sediment floor of the oceans; and the higher affinity of ${ }^{210} \mathrm{~Pb}$ for organic matter and suspended particles. The particles enriched in ${ }^{210} \mathrm{~Pb}$ are scavenged from 
water column and deposited in the sediment, creating an excess of ${ }^{210} \mathrm{~Pb}$ with respect to ${ }^{226} \mathrm{Ra}$ within the sediment. The total concentration of ${ }^{210} \mathrm{~Pb}$ in sediments is unequally distributed in two fractions: a constant supported fraction which originates in situ from the ${ }^{222} \mathrm{Rn}$ decay, and the excess fraction $\left({ }^{210} \mathrm{~Pb}\right.$ excess $)$ that, unders the assumption that ${ }^{210} \mathrm{~Pb}$ flux is constant, can be related with the sedimentation rate. The decline of ${ }^{210} \mathrm{~Pb}$ excess with sediment depth is proportional to the time elapsed since deposition, allowing the chronological reconstruction. The main source of particulate matter to the pelagic sediments is the upper ocean, where production of biogenic particles takes place. The relationship of ${ }^{210} \mathrm{~Pb}$ and organic carbon $\left(\mathrm{C}_{\text {org }}\right)$ is such that the inventory of ${ }^{210} \mathrm{~Pb}$ excess in sediments can be used as a proxy for the flux of $\mathrm{C}_{\text {org }}$ to the sediments (Moore and Dymondt, 1988).

Located at the subpolar gyre of the North Atlantic, the Irminger Basin is a semi-enclosed basin with a characteristic V-shaped (Figure 1), limited by the Denmark Strait, the coast of Greenland and the Reykjanes Ridge. The Irminger basin is considered part of the Atlantic sector of the Arctic Ocean (Tilling et al., 2015; Robson et al., 2018), and its northern limit (Denmark Strait) is the main gateway of arctic waters to the Atlantic Ocean at the eastern rim of Greenland (Jochumsen et al., 2017). The study zone is located in the central deepest part of the basin, where continental influence is very low. The Irminger basin is a well-recognized carbon sink area (Landschützer et al., 2016; Takahashi et al., 2009), with primary production dynamics characterized by the North Atlantic spring bloom (Henson et al., 2006) and where winter deep convection events occur regularly (de Jong and de Steur, 2016; Piron et al., 2017). Bottom circulation at the central Irminger Basin is dominated by Denmark Strait Overflow Water (DSOW), a precursor water mass of North Atlantic Deep Water and an important component of the southward flowing lower limb of the Atlantic Meridional Overturning Circulation (AMOC) (Våge et al., 2011). Furthermore, oceanographic properties with climate relevance have been reconstructed from North Atlantic high-resolution sediment chronologies with studies of past sea surface temperature (Miettinen et al., 2011; Moffa-Sanchez et al., 2014), bottom flow speed (Boessenkool et al; 2007, Mjell et al., 2016), or even the AMOC (Thornalley et al. 2018). These records reveal an unprecedented coupling in the changes between surface and deep ocean (Hall et al, 2010). 
Proxy-based records of modern sediments are necessary to discern natural and anthropogenic trends (Mjell et al., 2016). The amount of carbon buried into the sediments is also a biogeochemical property with relevance for the climate system. Despite its importance in the carbon cycle, the local magnitudes of carbon fluxes into the sediments are far from resolved. To broaden the scope of the results, and after the demonstration that sedimentation rates are similar in the relatively restricted and homogeneous study zone (section 3.1), we have combined the geochronology established for a single core (the dated core, from now on), with the geochemical analysis of a set of four deep-ocean sediment cores (>3000 m depth) located in the central Irminger Basin. This work is addressed to quantify the fluxes of particulate organic and inorganic carbon reaching the bottom of the central Irminger Basin in order to evaluate the role of this basin as a carbon sink during the Anthropocene.

\section{Materials and Methods}

Data were obtained from four sediment cores recovered in June-July 2016 from the central Irminger Basin (>3000 m depth) during the BOCATS/OVIDE cruise (R/V Sarmiento de Gamboa) (Fig. 1a). The sediment was retrieved using a box-corer that should ensure nearly intact sampling of the superficial sediment. Once aboard, four PVC tubes (67 mm diameter) were introduced avoiding the edges of the box-corer, in order to reduce the possible smearing effects. The box-corer was then disarmed without perturbation of the PVC tubes and well-preserved cores were immediately sampled aboard. Samples were sliced every $0.5 \mathrm{~cm}$ between the top centimeters 1 to 10 , and every $1 \mathrm{~cm}$ from $10 \mathrm{~cm}$ to bottom. High water content of the surface interphase prevented the separation of the top $0.5 \mathrm{~cm}$, so the first centimeter is also entire $(0-1 \mathrm{~cm})$. Samples were stored in a refrigerator at $4^{\circ} \mathrm{C}$. Plastic material was used for all the steps of slicing and storing. Water content was determined from the difference between wet and dry weights. Grain-size and geochemical analyses were done in an ISO9001 certified laboratory (CACTI, University of Vigo). 


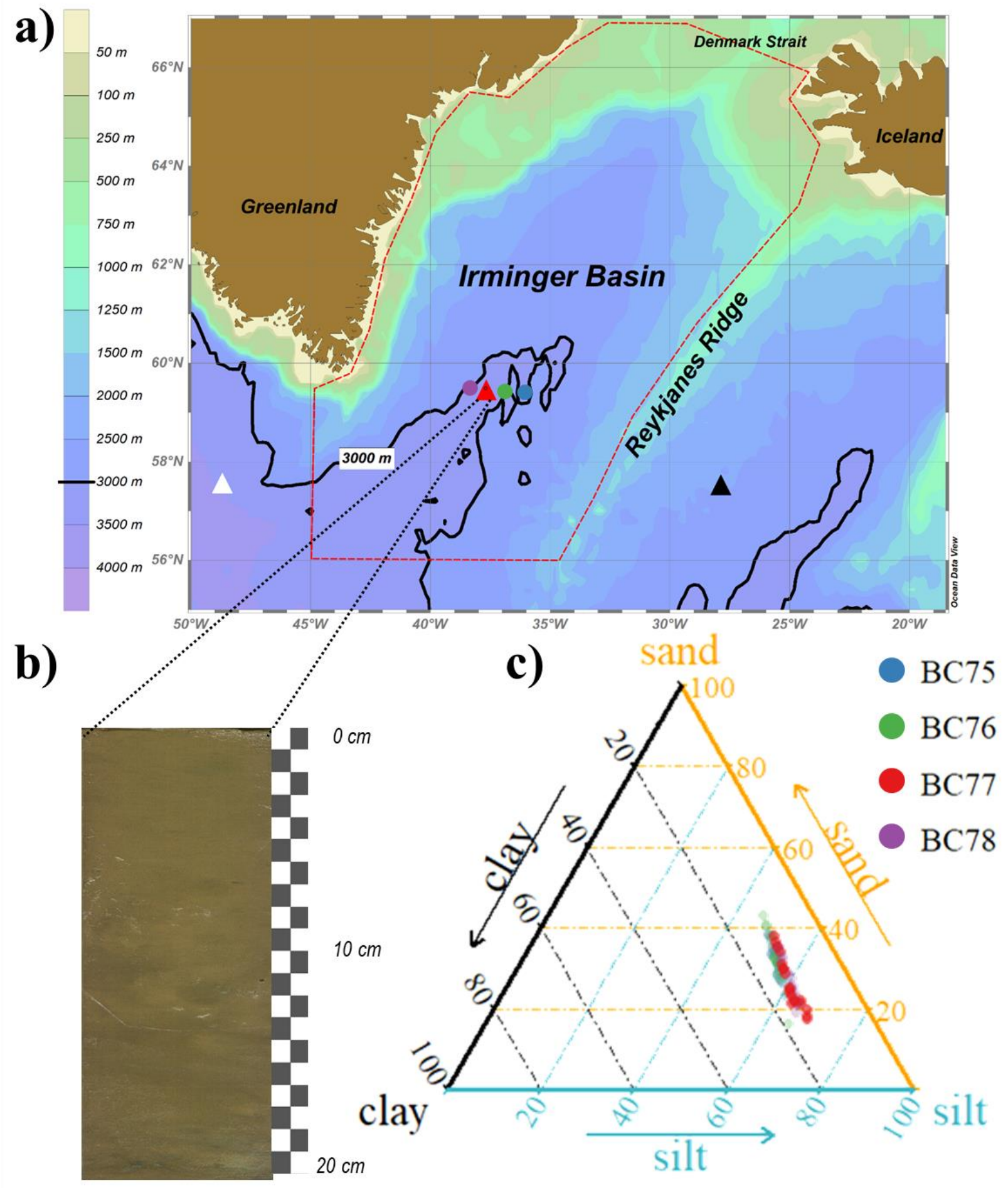

Figure 1. a) Map of the Irminger Basin. Location of the cores in the central Irminger Basin (>3000 m depth) is represented with colored points. The dated core $\left(B C 77,59^{\circ} 29.46^{\prime} \mathrm{N},-37^{\circ} 41.15^{\prime} \mathrm{W}\right)$ is represented by a red 
triangle. The $3000 \mathrm{~m}$ isobath is the thick black line, and the dashed red polygon represents the boundaries considered for the Irminger Basin. The site location of other studies discussed along the text are represented with a black triangle (Boessenkool et al., 2007; Jonkers et al., 2010b) and a white triangle (Moffa-Sánchez et al., 2014). b) Vertical image of the dated core in visible light from top $(0 \mathrm{~cm})$ to depth $(20 \mathrm{~cm})$. Each one of the vertical black and white rectangles at right side represent $1 \mathrm{~cm}$. c) Ternary diagram for the grain-size characterization of the samples from the study area. The color legend of the cores along its naming is available at the upper right corner.

121

122

123

124

125

126

127

128

129

130

131

132

133

134

135

136

137

138

139

140

141

142

\subsection{Sediment analysis:}

\subsubsection{Grain-size characterization}

Grain-size characterization was performed at centimetric resolution using a laser diffraction particle size analyser (Beckman Coulter LS 13320 with Fraunhofer optical model). Samples were calibrated with certified standards achieving an accuracy $(1.6 \mu \mathrm{m})$ and precision $(3 \mu \mathrm{m})$ well below the ISO 13320 norm for particle size analysis with laser scattering methods. Samples were split into clay $(<2 \mu \mathrm{m})$, silt $(2-63 \mu \mathrm{m})$ and sand $(>63$ $\mu \mathrm{m})$. Silt and sand fractions are subdivided by increasing size as very fine, fine, medium, coarse and very coarse (Fig. 2a).

\subsubsection{Radionuclide measurements}

For the radionuclide measurements, only applied to the dated core (BC77), oven dried samples $\left(45 \pm 2^{\circ} \mathrm{C}\right)$ were powdered in an agate ball-mill and vacuum-packed into plastic containers of a standard geometry with a known weight of around $\sim 15 \mathrm{~g}$ per sample. Samples were sealed at least three weeks before being measured to ensure that secular equilibrium between parent isotope ${ }^{226} \mathrm{Ra}$ and its short-lived daughter isotopes was reached. Samples were counted in a low level background gamma-ray spectrometer with two hyper-pure germanium (HPGe) planar detectors (BEGe Model, Canberra) coupled with a multichannel analyzer. In order to reduce the background level as much as possible a series of active and passive shieldings were developed: (i) each detector is mounted in an impurity-free cryostat (ii) and surrounded by anti-Compton rings (Nal(TI), Scionix), (iii) the chamber of detection is shielded with uncontaminated iron (10 cm thick) and lead (5 
$\mathrm{cm}$ thick) dating from the Eighteenth Century, (iv) and is continuously ventilated with nitrogen gas in order to avoid inferences due radon accumulation. Furthermore (v), all the equipment is installed in a third basement, reducing the cosmogenic radiation.

Individual samples were counted between 48-96 hours until statistically significant emission's spectra were achieved. Total activity of ${ }^{210} \mathrm{~Pb},{ }^{226} \mathrm{Ra}$ and ${ }^{214} \mathrm{~Pb}$, the radionuclides used for the dating, was determined by gamma emission at $46.54 \mathrm{keV}$, $186.21 \mathrm{keV}$ and $351.93 \mathrm{keV}$, respectively. In a similar way, total activity of the anthropogenic radionuclides ${ }^{241} \mathrm{Am}$ and ${ }^{137} \mathrm{Cs}$ was determined by their gamma emission at $59.54 \mathrm{keV}$ and $661.65 \mathrm{keV}$, respectively. Assuming secular equilibrium between ${ }^{226} \mathrm{Ra}$ and its daughter nuclide ${ }^{214} \mathrm{~Pb}$, the specific activity of ${ }^{210} \mathrm{~Pb}$ excess is the difference between the activities of ${ }^{210} \mathrm{~Pb}$ and ${ }^{214} \mathrm{~Pb}$. The equipment was adequately calibrated in energy and efficiency. Energy calibration is done together with an optimum spectrum analysis using the software Galea (Quintana and Fernández, 1998), developed for the optimization of gamma emission spectra from natural radionuclides. For the efficiency calibration, replicated samples were spiked with known radioactive standard solutions (Quintana et al., 2017). In total, 30 sources were analyzed for specific activities determined by gamma spectrometry. The counting times were increased according with the depth of the sample from 24 to $72 \mathrm{~h}$, providing a measurement precision of $5 \%$ to $10 \%$ at the $95 \%$ level of confidence. Efficiencies obtained are 0.3073(90), 0.2544(92), and 0.1612(44) at 46.54 $\mathrm{keV}\left({ }^{210} \mathrm{~Pb}\right), 186.21 \mathrm{keV}\left({ }^{226} \mathrm{Ra}\right)$ and $351.93 \mathrm{keV}\left({ }^{214} \mathrm{~Pb}\right)$ respectively. For the anthropogenic radionuclides the efficiencies obtained were $0.0710(19)$ for ${ }^{137} \mathrm{Cs}$ and $0.3221(68)$ for ${ }^{241} \mathrm{Am}$.

\subsubsection{Geochemistry profile}

For all the four cores, semi-quantitative analysis of the carbon composition has been done on dried sub-samples with a LECO CN system analyzer following the loss-on-ignition method (Schumacher, 2002). After a first determination of total carbon (TC), the aliquot is heated overnight under $350-440^{\circ} \mathrm{C}$ in order to remove the organic fraction prior to a second analysis. The second determination represents the total inorganic carbon fraction (TIC). Total organic carbon (TOC) is the difference between TC and TIC. Measurements were calibrated with a standard sediment sample with $\mathrm{CaCO}_{3}$ before analysis. Accuracy 
173 and precision in carbon element content is $0.4 \%$ relative standard deviation and the limit 174 of detection is $0.25 \%$.

175 For the dated core (BC77), - a geochemical characterization has been measured all along 176 the core at a spatial resolution of $2 \mathrm{~mm}$ by means of a high-resolution XRF core scanner 177 (ITRAX ${ }^{T M}$ ) (Frigola et al., 2015; Rothwell and Croudace, 2015). These measurements 178 allowed semi-quantitative estimates, since the intensity of the XRF spectrum for each 179 single element is proportional to its concentration (Richter et al., 2006). XRF data were 180 measured using a Molybdenum (Mo) X-ray tube anode with a voltage of $30 \mathrm{kV}$, a current 181 of $55 \mathrm{~mA}$ and an exposure time of $20 \mathrm{~s}$, and processed using the Q-Spec 8.6.0 software 182 (Cox Analytical Systems, Sweden). The Mo-tube is more efficient in the detection of 183 heavier (K, Ca, Ti, Fe, Sr) than lighter elements (Mg, Al, Si) (Rodríguez-Germade et al., 184 2015).

\section{$185 \quad 2.2$ Age model}

186 The Constant Rate of Supply (CRS) model was selected for core dating (Krishnaswamy 187 et al., 1971). Conceptual ${ }^{210} \mathrm{~Pb}$ models used to date undisturbed sediment cores can be 188 derived from a single fundamental equation (Eq. 1) (Sanchez-Cabeza and Ruiz189 Fernández, 2012), that relates the concentration of ${ }^{210} \mathrm{~Pb}$ excess in interval (i) at the time of formation $C(i, t=$ 0 ) as the ratio between the ${ }^{210} \mathrm{~Pb}$ excess flux to the sediment surface $(f(i))$ and the accumulation rate $(r(i))$. Once section (i) is formed, ${ }^{210} \mathrm{~Pb}$ excess inventory $(\mathrm{A})$ decays exponentially following the radioactive decay law (Eq. 2):

$$
A_{i}=A_{0} \cdot e^{-\lambda t_{(i)}}
$$

(Equation 2)

196

197

$$
C(i, t=0)=\frac{f(i)}{r(i)}
$$

The ${ }^{210} \mathrm{~Pb}$ excess inventory measured in interval (i) $\left(A_{i}\right)$, can be related with the ${ }^{210} \mathrm{Pbexcess}$ inventory at actual time "zero" (Ao, i.e., the total inventory of the core) taking into account the time elapsed $\left(t_{(i)}\right)$ and the disintegration constant of ${ }^{210} \mathrm{~Pb}$ isotope $\left(\lambda=0.03118 \pm 0.00017 \mathrm{yr}^{-1}\right)$. Following Eq.2 can be calculated the age of section (i) as (Eq. 3):

$$
t_{(i)}=\frac{1}{\lambda} \ln \left(\frac{A_{0}}{A_{(i)}}\right)
$$

(Equation 3) 
202 The fundamental assumption of the model is that the supply of ${ }^{210} \mathrm{~Pb}$ excess flux from the atmosphere to the ocean and from the water column to the sediment surface are constant, while the sedimentation rate might vary (Appleby and Oldfield, 1983; Sanchez-Cabeza et al., 2000), and no redistribution processes occur in the sediment (Mabit et al., 2014). To take into account sediment compaction, the dating was performed as a function of mass depth $\left(\mathrm{kg} \cdot \mathrm{m}^{-2}\right)$. A requirement for this model is that is mandatory to know the total inventory $\left(A_{0}\right)$ in order to date. If the total ${ }^{210} \mathrm{~Pb}$ profile does not reach the supported value at the bottom it will have an underestimated inventory and dating capabilities would be compromised.

Once time between samples is known, mass accumulation rates (MAR, $\mathrm{cm} \cdot \mathrm{yr}^{-1}$ ) can be calculated simply as the ratio of the same intervals for depth $\left(z_{i+1}-z_{i}\right)$ and time $\left(t_{i}-\right.$ $\left.213 t_{i+1}\right)($ Eq. 4):

$$
M A R_{i}=\frac{\left(z_{i+1}-z_{i}\right)}{\left(t_{i}-t_{i+1}\right)}
$$

(Equation 4)

The total mass can be obtained with the slope of the log-linear relationship between ${ }^{210} \mathrm{~Pb}$ excess activity and mass depth at each interval, combined with the known decay in time of the ${ }^{210} \mathrm{~Pb}$ isotope.

\subsection{Carbon fluxes}

We determined the organic and inorganic carbon fluxes combining the representative carbon elemental composition profile for the central Irminger with the MAR obtained by ${ }^{210} \mathrm{~Pb}$ excess profiles from the dated core. For each layer (i), maximum carbon flux rates $\left(\mathrm{C}_{\mathrm{f}(\mathrm{i})}, \mathrm{mg}-\mathrm{C} \cdot \mathrm{cm}^{-2} \cdot \mathrm{yr}^{-1}\right)$ were calculated (Eq. 5) as the product of MAR derived from the dating model $\left(\mathrm{cm} \cdot \mathrm{yr}^{-1}\right)$, the representative carbon concentrations $\left(\mathrm{C}_{\mathrm{c}}, \mathrm{mg} \cdot \mathrm{g}^{-1}\right)$ and the dry bulk density $\left(\rho, \mathrm{g} \cdot \mathrm{cm}^{-3}\right)$ of the dated core. The dry bulk density is estimated for each layer as the ratio between the dry mass of the layer (weight) and its known volume.

$$
C_{f(i)}=C_{c(i)} * \operatorname{MAR}_{(i)} * \rho_{(i)}
$$

Table 1. Specific activities for the radionuclides ${ }^{210} \mathrm{~Pb},{ }^{214} \mathrm{~Pb},{ }^{226} \mathrm{Ra}$ and for the ${ }^{210} \mathrm{~Pb}$ excess term, along with age and sedimentation rate obtained for each depth.

\begin{tabular}{|l|c|c|c|c|c|c|c|c|}
\hline $\begin{array}{c}\text { Depth } \\
(\mathrm{cm})\end{array}$ & $\begin{array}{c}{ }^{210} \mathrm{~Pb} \\
\left(\mathrm{~Bq} \cdot \mathrm{kg}^{-1}\right)\end{array}$ & $\begin{array}{c}{ }^{214} \mathrm{~Pb} \\
\left(\mathrm{~Bq} \cdot \mathrm{kg}^{-1}\right)\end{array}$ & $\begin{array}{c}{ }^{226} \mathrm{Ra} \\
\left(\mathrm{Bq} \cdot \mathrm{kg}^{-1}\right)\end{array}$ & $\begin{array}{c}{ }^{210} \mathrm{~Pb}_{\text {excess }} \\
\left(\mathrm{Bq} \cdot \mathrm{kg}^{-1}\right)\end{array}$ & $\begin{array}{c}\text { Age } \\
(\mathrm{CE})\end{array}$ & $\begin{array}{c}\text { Sedimentation } \\
\text { rate }\left(\mathrm{mm} \mathrm{yr}^{-1}\right)\end{array}$ & $\begin{array}{c}\text { Organic } \\
\text { carbon flux } \\
\left(\mathrm{g}-\mathrm{C}_{\text {org }} \cdot \mathrm{m}^{-}\right. \\
\left.2^{-} \cdot \mathrm{yr}^{-1}\right)\end{array}$ & $\begin{array}{c}\text { Inorganic } \\
\text { carbon flux } \\
\left(\mathrm{g}-\mathrm{C}_{\text {inorg }} \cdot \mathrm{m}^{-}\right. \\
\left.2^{-} \mathrm{yr}^{-1}\right)\end{array}$ \\
\hline 1 & $188.7 \pm 6.3$ & $26.61 \pm 0.85$ & $27 \pm 18$ & $162.1 \pm 6.3$ & $2010.0 \pm 1.0$ & $0.76 \pm 0.12$ & $3.65 \pm 0.77$ & $21.7 \pm 6.9$ \\
\hline 1.5 & $160.8 \pm 5.6$ & $27.87 \pm 0.93$ & $24.8 \pm 8.5$ & $133.0 \pm 5.7$ & $2005.6 \pm 1.1$ & $0.73 \pm 0.14$ & $5.6 \pm 1.7$ & $28.0 \pm 9.3$ \\
\hline
\end{tabular}




\begin{tabular}{|c|c|c|c|c|c|c|c|c|}
\hline 2 & $200.5 \pm 6.8$ & $27.51 \pm 0.94$ & $35.5 \pm 6.6$ & $173.0 \pm 6.8$ & $1998.8 \pm 1.4$ & $0.89 \pm 0.11$ & $7.8 \pm 2.8$ & $34 \pm 10$ \\
\hline 2.5 & $148.9 \pm 5.2$ & $25.23 \pm 0.9$ & $28.8 \pm 3.2$ & $123.6 \pm 5.3$ & $1993.2 \pm 1.6$ & $1.23 \pm 0.13$ & $8.8 \pm 2.2$ & $45 \pm 13$ \\
\hline 3 & $92.2 \pm 3.5$ & $29.41 \pm 0.97$ & $30.4 \pm 9.0$ & $62.8 \pm 3.6$ & $1989.1 \pm 1.8$ & $1.43 \pm 0.13$ & $10.4 \pm 1.5$ & $65 \pm 19$ \\
\hline 3.5 & $85.1 \pm 3.1$ & $29.38 \pm 0.94$ & $27 \pm 18$ & $55.7 \pm 3.3$ & $1985.6 \pm 2.0$ & $1.10 \pm 0.10$ & $6.81 \pm 0.93$ & $42 \pm 12$ \\
\hline 4 & $93.7 \pm 3.5$ & $27.13 \pm 0.93$ & $26 \pm 10$ & $66.6 \pm 3.6$ & $1981.1 \pm 2.3$ & $1.27 \pm 0.11$ & $7.42 \pm 0.94$ & $45 \pm 13$ \\
\hline 4.5 & $76.4 \pm 2.9$ & $30.56 \pm 0.97$ & $31.3 \pm 3.9$ & $45.8 \pm 3.1$ & $1977.2 \pm 2.6$ & $0.99 \pm 0.09$ & $6.48 \pm 0.75$ & $39 \pm 12$ \\
\hline 5 & $76.6 \pm 3.1$ & $29.90 \pm 0.99$ & $33 \pm 12$ & $46.7 \pm 3.3$ & $1972.1 \pm 3.0$ & $1.51 \pm 0.14$ & $10.9 \pm 1.2$ & $65 \pm 22$ \\
\hline 5.5 & $60.3 \pm 2.2$ & $32.2 \pm 1.0$ & $33 \pm 18$ & $28.1 \pm 2.4$ & $1968.8 \pm 3.3$ & $1.44 \pm 0.14$ & $9.4 \pm 1.0$ & $59 \pm 21$ \\
\hline 6 & $56.7 \pm 2.1$ & $31.91 \pm 0.94$ & $30 \pm 15$ & $24.8 \pm 2.3$ & $1965.3 \pm 3.7$ & $1.17 \pm 0.12$ & $7.70 \pm 0.83$ & $50 \pm 20$ \\
\hline 6.5 & $57.4 \pm 2.1$ & $31.98 \pm 0.99$ & $33.1 \pm 8.1$ & $25.4 \pm 2.4$ & $1961 \pm 4.2$ & $1.62 \pm 0.17$ & $10.9 \pm 1.5$ & $73 \pm 25$ \\
\hline 7 & $49.6 \pm 1.8$ & $32.36 \pm 0.99$ & $34.8 \pm 6.2$ & $17.3 \pm 2.1$ & $1957.9 \pm 4.7$ & $2.59 \pm 0.29$ & $15.9 \pm 2.9$ & $109 \pm 31$ \\
\hline 7.5 & $41.4 \pm 1.6$ & $32.25 \pm 0.97$ & $32.1 \pm 2.6$ & $9.1 \pm 1.9$ & $1956 \pm 5.0$ & $2.03 \pm 0.23$ & $12.1 \pm 2.2$ & $91 \pm 27$ \\
\hline 8 & $43.3 \pm 1.7$ & $32.72 \pm 0.97$ & $38.0 \pm 3.3$ & $10.6 \pm 2.0$ & $1953.5 \pm 5.4$ & $1.15 \pm 0.14$ & $6.2 \pm 1.2$ & $51 \pm 16$ \\
\hline 8.5 & $50.5 \pm 1.8$ & $33.07 \pm 0.97$ & $37 \pm 11$ & $17.4 \pm 2.1$ & $1949.2 \pm 6.2$ & $1.02 \pm 0.13$ & $5.9 \pm 1.0$ & $44 \pm 16$ \\
\hline 9 & $47.0 \pm 1.7$ & $30.93 \pm 0.91$ & $36.5 \pm 3.9$ & $16.0 \pm 1.9$ & $1944.3 \pm 7.2$ & $1.63 \pm 0.22$ & $11.2 \pm 1.8$ & $76 \pm 30$ \\
\hline 9.5 & $42.6 \pm 1.6$ & $33.8 \pm 1.0$ & $32 \pm 14$ & $8.8 \pm 1.9$ & $1941.2 \pm 8.0$ & $3.19 \pm 0.47$ & $25.0 \pm 4.5$ & $141 \pm 50$ \\
\hline 10 & $37.0 \pm 1.5$ & $32.99 \pm 0.99$ & $34 \pm 11$ & $4.1 \pm 1.8$ & $1939.6 \pm 8.4$ & $3.27 \pm 0.50$ & $28.9 \pm 5.6$ & $138 \pm 43$ \\
\hline 11 & $37.0 \pm 1.4$ & $33.39 \pm 0.94$ & $39.8 \pm 6.6$ & $3.7 \pm 1.7$ & $1936.6 \pm 9.3$ & $2.35 \pm 0.38$ & $16.1 \pm 3.2$ & $95 \pm 46$ \\
\hline 12 & $38.1 \pm 1.4$ & $33.52 \pm 0.96$ & $36.0 \pm 6.2$ & $4.6 \pm 1.7$ & $1932 \pm 11$ & $4.37 \pm 0.76$ & $35.3 \pm 7.1$ & $186 \pm 100$ \\
\hline 13 & $36.0 \pm 1.4$ & $33.98 \pm 0.97$ & $34.9 \pm 6.3$ & $2.0 \pm 1.7$ & $1930 \pm 12$ & $1.03 \pm 0.19$ & $10.4 \pm 2.1$ & $48 \pm 24$ \\
\hline 14 & $33.5 \pm 1.3$ & $26.35 \pm 0.77$ & $27.5 \pm 9.9$ & $7.2 \pm 1.5$ & $1920 \pm 16$ & $1.88 \pm 0.40$ & $18.5 \pm 4.5$ & $71 \pm 26$ \\
\hline 15 & $35.2 \pm 1.5$ & $32.13 \pm 0.95$ & $31.6 \pm 7.6$ & $3.1 \pm 1.7$ & $1915 \pm 19$ & $0.95 \pm 0.24$ & $6.6 \pm 1.7$ & $35 \pm 18$ \\
\hline 16 & $34.9 \pm 1.4$ & $30.11 \pm 0.90$ & $29.0 \pm 8.4$ & $4.8 \pm 1.7$ & $1905 \pm 27$ & $1.42 \pm 0.44$ & $11.1 \pm 3.7$ & $48 \pm 22$ \\
\hline 17 & $32.7 \pm 1.5$ & $30.42 \pm 0.92$ & $32 \pm 11$ & $2.3 \pm 1.7$ & $1897 \pm 34$ & $0.49 \pm 0.18$ & $4.2 \pm 1.6$ & $15.7 \pm 9.5$ \\
\hline 18 & $34.8 \pm 1.5$ & $29.91 \pm 0.90$ & $28 \pm 12$ & $4.8 \pm 1.7$ & $1877 \pm 66$ & $0.81 \pm 0.44$ & $5.9 \pm 3.4$ & $21 \pm 13$ \\
\hline 19 & $30.8 \pm 1.4$ & $29.00 \pm 0.92$ & $26 \pm 12$ & $1.8 \pm 1.7$ & $1865 \pm 98$ & $0.50 \pm 0.40$ & $3.2 \pm 2.6$ & $9.3 \pm 8.1$ \\
\hline 20 & $31.9 \pm 1.5$ & $30.15 \pm 0.90$ & $28 \pm 10$ & $1.8 \pm 1.7$ & $1845 \pm 184$ & $1.0 \pm 1.3$ & $6.8 \pm 8.9$ & $26 \pm 36$ \\
\hline
\end{tabular}

$230 \quad 3$ Results

\section{$231 \quad 3.1$ Grain-size characterization}

232 Particle size analysis identified the percentage of clay, silt and sand at centimetric 233 resolution in each of the cores (Fig. 2a). The dated core (BC77, 59 29.46' N, 37 41.15' 234 W, $3118 \mathrm{~m}$ water depth, $20 \mathrm{~cm}$, red triangle in Fig.1a) consists of ochre calcareous oozes 235 (sandy silt texture, Fig. 1c). Despite looking quite homogenous visually (Fig. 1b), a 236 detailed description and grain-size analysis (Figure 2a) distinguish three intervals. Bottom 237 interval $(20-14 \mathrm{~cm})$ is the siltiest interval (61-68\%). Sand fraction, mainly very fine and 238 fine sand, represents less than $25 \%$ and the mean grain-size is around 16-18 $\mu \mathrm{m}$. 
239 Percentage of silt (56-63\%) slightly decreases in the middle interval $(14-6 \mathrm{~cm})$, where the 240 amount of sand increases upwards from $22 \%$ at the base up to $31 \%$ at the top. Mean 241 grain size oscillates due to bioturbation observed in this interval. The youngest interval is 242 coarser (mean grain-size is $24-28 \mu \mathrm{m}$ ) due to higher abundance of fine and very fine sand 243 fractions (34-38\% of sand). Most of the grains of sand correspond to foraminiferal tests.

244 As a whole, the dated core shows a clear coarsening upwards trend, caused by the 245 progressively increase of fine sand and the decreasing percentages of very coarse silt. 246 All the cores of the central Irminger show similar grain-size composition (Fig. 1c), 247 distribution and trends (Fig.2a) to the dated core, an evidence that supports that mass 248 accumulation rates are not significantly different among the studied cores. An exhaustive 249 description of the grain size parameters for the other three cores is out of the scope of 250 the current work. 

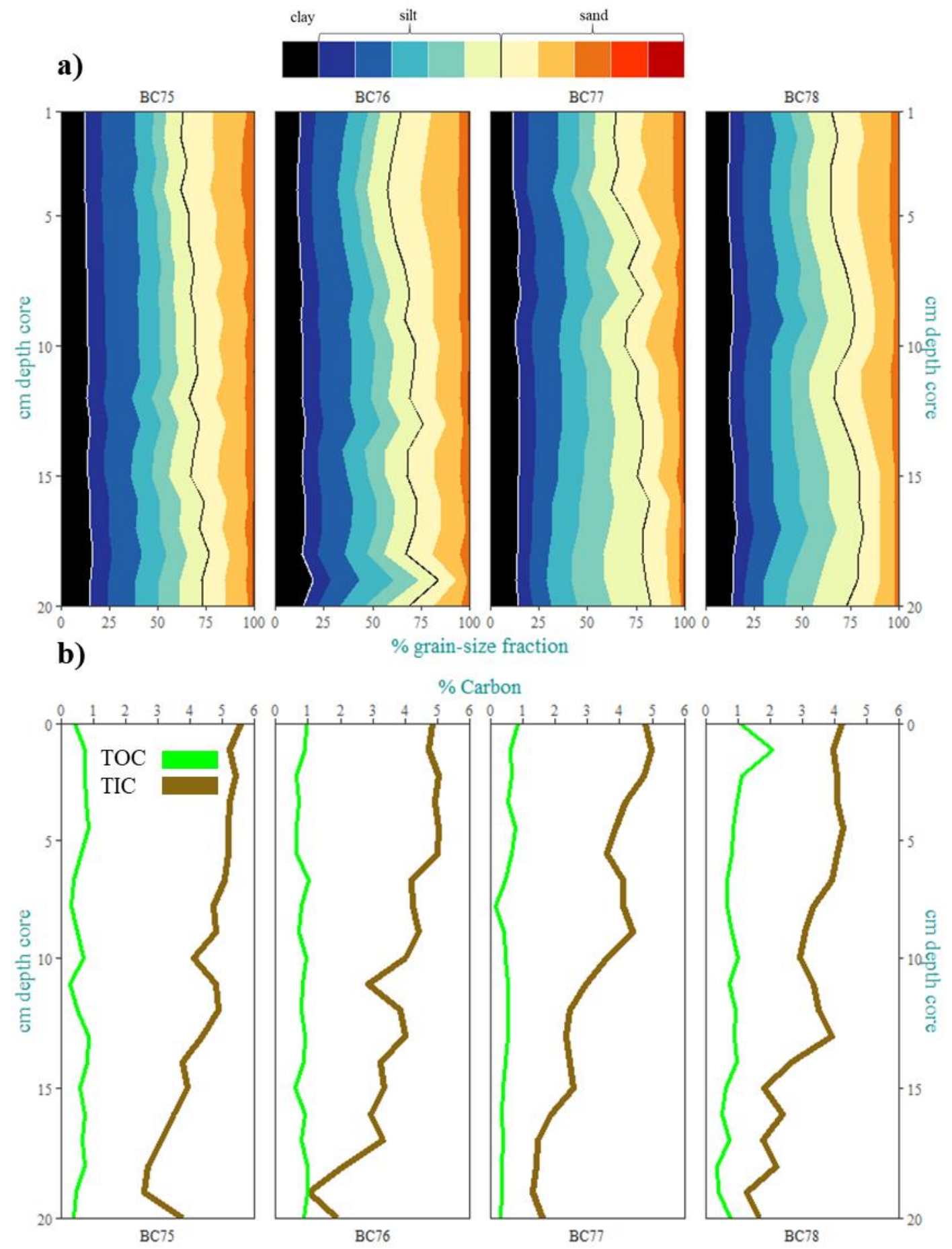

Figure 2. For the four cores of the central Irminger Basin, a) vertical distributions (cm) of the grain-size fractions clay(black), silt (increasing size from dark blue to yellowish) and sand (from pale white to red) with respect to the mass contribution (\%). Black line separates the fractions very coarse silt and very fine sand. b) vertical distributions $(\mathrm{cm})$ 
of total inorganic carbon (TIC, brown) and total organic carbon (TOC, green) with respect to the mass contribution (\%).

\subsection{Core dating}

All sediment radionuclide concentrations for the dated core are given in $\mathrm{Bq} \cdot \mathrm{kg}^{-1}$ dry weight (Table 1). Minimum detectable activities (MDA) depend on radionuclide gamma energy, count time and sample mass, but were typically below $0.60 \mathrm{~Bq} \cdot \mathrm{kg}^{-1}$ for ${ }^{210} \mathrm{~Pb}, 0.56 \mathrm{~Bq} \cdot \mathrm{kg}^{-}$ ${ }^{1}$ for ${ }^{214} \mathrm{~Pb}$ and $2.26 \mathrm{~Bq} \cdot \mathrm{kg}^{-1}$ for ${ }^{226} \mathrm{Ra}$. The vertical distributions of ${ }^{210} \mathrm{~Pb},{ }^{214} \mathrm{~Pb}$ and ${ }^{226} \mathrm{Ra}$ specific activities and its uncertainties for the dated core are given in Fig. 3a. The specific activities for radionuclide ${ }^{210} \mathrm{~Pb}$ are detected along the whole dated core, with maxima at surface and a clearly diminishing exponential profile towards deeper sediments. Total ${ }^{210} \mathrm{~Pb}$ specific activities range from 30.8(1.4) Bq $\cdot \mathrm{kg}^{-1}$ to $200.5(6.8) \mathrm{Bq} \cdot \mathrm{kg}^{-1}$. Total ${ }^{226} \mathrm{Ra}$ specific activities range from $24.8(8.5)$ $\mathrm{Bq} \cdot \mathrm{kg}^{-1}$ to $39.8(6.6) \mathrm{Bq} \cdot \mathrm{kg}^{-1}$. The ${ }^{214} \mathrm{~Pb}$ specific activity is relatively constant around 30 $\mathrm{Bq} \cdot \mathrm{kg}^{-1}$, ranging between $25.23(0.90) \mathrm{Bq} \cdot \mathrm{kg}^{-1}$ to $33.98(0.97) \mathrm{Bq} \cdot \mathrm{kg}^{-1}$. The fact that specific activity of ${ }^{214} \mathrm{~Pb}$ have smaller uncertainties than ${ }^{226} \mathrm{Ra}$, less than $1 \mathrm{~Bq} \cdot \mathrm{kg}^{-1}$ usually, suggests that ${ }^{226} \mathrm{Ra}$ activities are derived from ${ }^{214} \mathrm{~Pb}$. Furthermore, the relative vertical distribution of ${ }^{214} \mathrm{~Pb}$ and ${ }^{226} \mathrm{Ra}$ (Fig. 3a) supports the assumption of secular equilibrium between them, so the excess of ${ }^{210} \mathrm{~Pb}\left({ }^{210} \mathrm{~Pb}\right.$ excess $)$ can be obtained as the difference of the total ${ }^{210} \mathrm{~Pb}$ with respect to ${ }^{214} \mathrm{~Pb}$. The ${ }^{210} \mathrm{~Pb}$ excess fraction is observed in the first $10 \mathrm{~cm}$ of the dated core. ${ }^{210} \mathrm{~Pb}$ excess specific activity decays following an exponential profile towards the bottom, and it shows a maximum at subsurface $\left(2 \mathrm{~cm}, 173.0(6.8) \mathrm{Bq} \cdot \mathrm{kg}^{-1}\right)$.

271 The core was deep enough to reach the supported value before the bottom, so the 272 complete total ${ }^{210} \mathrm{~Pb}_{\text {excess }}$ inventory was determined at $5.13(0.098) \mathrm{kBq} \cdot \mathrm{m}^{-2}$, what 273 supposes a corresponding flux of $29.9(0.5) \mathrm{Bq} \cdot \mathrm{m}^{-2} \cdot \mathrm{yr}^{-1}$. In mass, the total flux is 1192(519) $274 \mathrm{~g} \cdot \mathrm{m}^{-2} \cdot \mathrm{yr}^{-1}$. 
a)

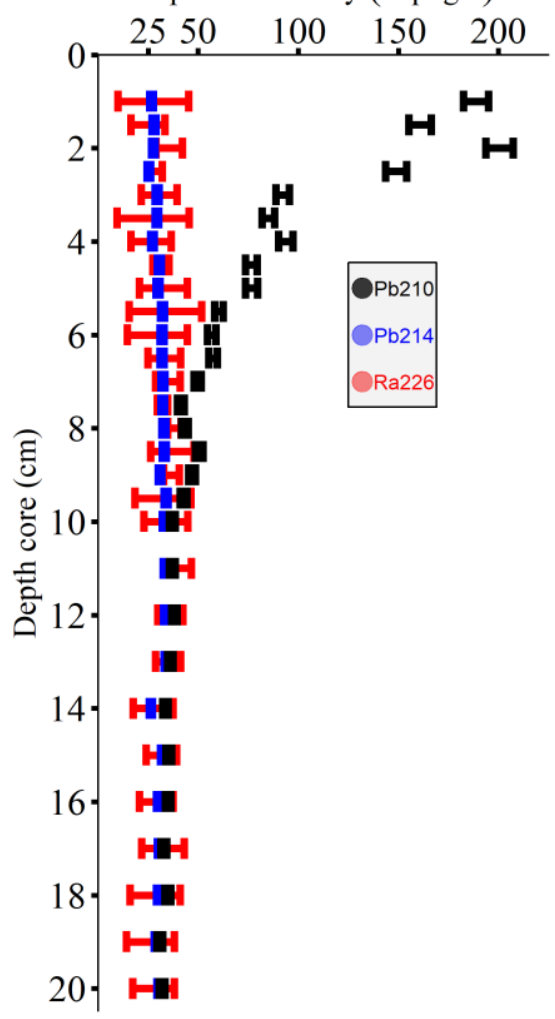

b)

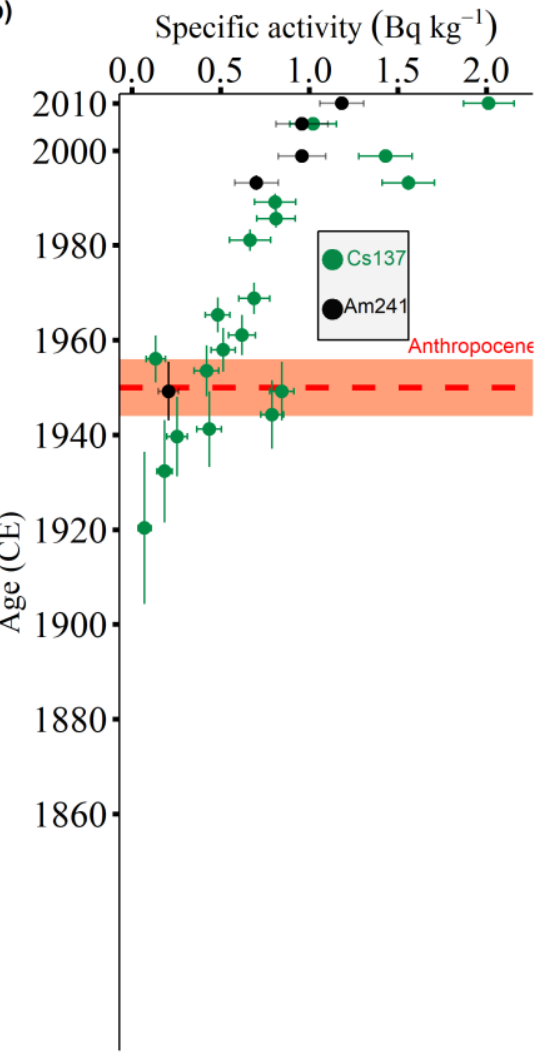

c)

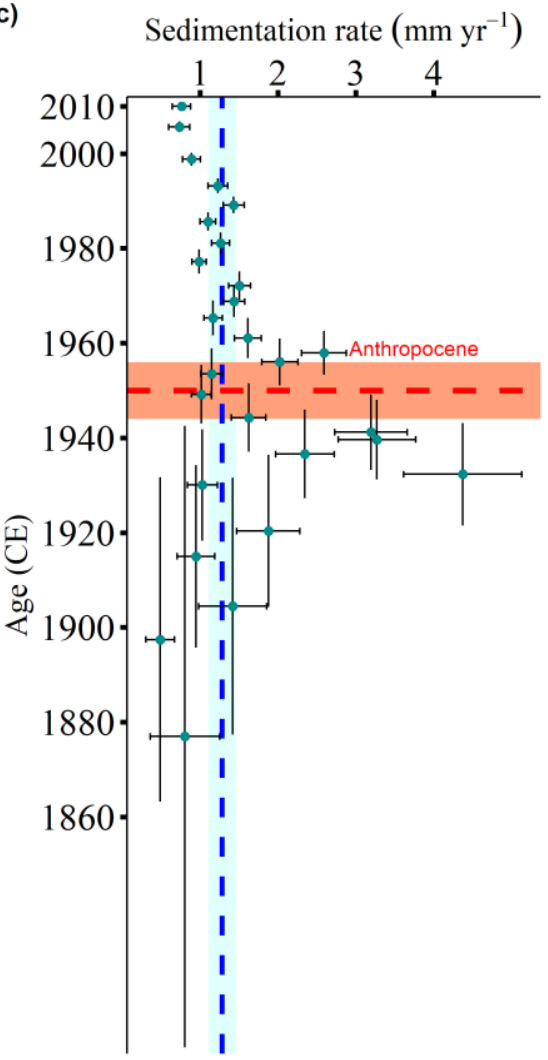

Figure 3. For the dated core, a) vertical distributions (cm) of specific activities $\left(\mathrm{Bq} \cdot \mathrm{kg}^{-1}\right)$ and its uncertainties for the radionuclides: ${ }^{210} \mathrm{~Pb}$ (black), ${ }^{214} \mathrm{~Pb}$ (blue) and ${ }^{226} \mathrm{Ra}$ (red). b) Time evolution of specific activities (Bq. $\mathrm{kg}^{-}$ 1) for the anthropogenic radionuclides ${ }^{137} \mathrm{Cs}$ (green) and ${ }^{241} \mathrm{Am}$ (black). The length of the vertical (horizontal) line correspond to the uncertainty in the specific activity (age). And c), time evolution of sedimentation rate obtained with the CRS model. The length of the vertical (horizontal) line correspond to the uncertainty in the sedimentation rate (age). Depicted in blue is the mean value for the sedimentation rate along with its uncertainty: $1.28 \pm 0.18 \mathrm{~mm} \cdot \mathrm{yr}^{-1} . \mathrm{In} \mathrm{b}$ ) and c) the dashed red line represent the onset of the Anthropocene at $1950 \mathrm{CE}$ along with the uncertainty in our dating at that time $( \pm 6 \mathrm{yr})$.

Dates and sedimentation rates with its correspondent uncertainties have been obtained 278 for each layer in the dated core by applying the CRS model (Table 1). As we move backward in time the uncertainties in age and sedimentation rate become larger. This is 
a common feature in all dating models based in short-lived radionuclides with propagation errors; and is the reason why the difference in years between the top of the core (time zero, summer 2016) and the last centimeter dated (179 \pm 190 years) shows such a large error while the error in the first hundred years dated is only \pm 15 years (Table 1 ). Taking into account the half-life of the ${ }^{210} \mathrm{~Pb}$ radionuclide $(22.23 \mathrm{yr})$, the maximum period of time datable using this technique with relative confidence is 100-150 years (Mabit et al., 2014). In our core, that temporal range comprehends the first $15 \mathrm{~cm}$, with an estimated date of $1885 \pm 43$. From now on, the results and discussion related with age and sedimentation rate will be limited to that temporal range.

The activities found for artificial radionuclides ${ }^{137} \mathrm{Cs}$ and ${ }^{241} \mathrm{Am}$ show maximum values at present times (Fig 3b). The maximum specific activity detected for ${ }^{137} \mathrm{Cs}$ is $2.014(0.144)$ $\mathrm{Bq} \cdot \mathrm{kg}^{-1}$ and $1.184(0.124)$ for ${ }^{241} \mathrm{Am}$. The first presence of ${ }^{241} \mathrm{Am}$ is near 1950 and ${ }^{137} \mathrm{Cs}$ is detected until the depth corresponding with the year 1920.

Analyzing the chronological framework, the mean weighted sedimentation rate is as high as $1.28 \pm 0.18 \mathrm{~mm} \cdot \mathrm{yr}^{-1}$. The time-evolution of sedimentation rates (Fig. $3 \mathrm{c}$ ) shows that the end of the XIX ${ }^{\text {th }}$ century, the sedimentation rates were similar to those from the most recent period, with values between 1-2 mm-yr-1. Then, at the at the end of the first half of the $X X^{\text {th }}$ century there was an important increase in the sedimentation rate $(4.37 \pm 0.76$ $\mathrm{mm} \cdot \mathrm{yr}^{-1}$, more than three-fold the mean value). After that short-lived maximum event, from 1960 CE to now the sedimentation rate shows a slightly decreasing trend.

\subsection{Geochemical evolution}

Carbon elemental composition for each core was obtained at centimetric resolution. For all the cores, the vertical distributions of TIC and TOC until the maximum depth in the dated core $(20 \mathrm{~cm})$ are shown in Fig.2b. Same as with the grain-size distribution, a quantitative and qualitative comparison between the profiles shows close similarity among them. The present study is aimed to determine current carbon fluxes in a relatively wide area rather than giving a punctual local estimate. Then, supported by the similarities showed for these pelagic cores we have assumed that the cores of the central Irminger Basin share the same age at the same depths, allowing the integration of a representative carbon elemental composition profile. The utilization of a representative carbon profile 
311 smooths two disadvantageous characteristics inherent to the experimental design: the

312 sediment patchiness due the sampling procedure and the uncertainty derived from the 313 semi-quantitative analysis of carbon composition. The representative carbon content 314 profile for the central Irminger is calculated as the mean composition at the same depths 315 for all the cores, with the uncertainties calculated as the standard error of the mean. Time 316 evolution representative carbon profiles of TC and its components TOC and TIC for the 317 central Irminger are in Fig. $4 a-b$. The content of TC ranged between $2 \pm 0.3 \%$ to $5.8 \pm 0.1 \%$ 318 with an increasing trend towards younger sediments ( $p$-value <0.001). The last $60 \mathrm{yr}$ records higher values in TC that previous decades. Around $90 \%$ of the carbon present is TIC. TOC content is pretty constant, ranging between $0.55-0.93 \%$, with the highest value in sub-surface. The TOC burial efficiency, or the percentage of deposited Corg preserved in the sediments, can be estimated with the concentration at the top of the core and the constant concentration at depth where it has undergone some diagenesis (Masqué et al., 2002). For the central Irminger Basin, the Corg burial efficiency was about $\sim 70 \%$. $\mathrm{X}$-ray fluorescence (XRF) measurements data for the biogenic proxy $\mathrm{Ca}$ and the terrigenous proxy $\mathrm{Fe}$ in the dated core are represented normalized by $\mathrm{Ti}$ (Fig. $4 \mathrm{c}-\mathrm{d}$ ). $\mathrm{Ca} / \mathrm{Ti}$ profile, as it occurs with previous proxies, shows a clearly increasing trend with recent time, with an enhanced biogenic fraction during the latest 50 years. The increasing trend is statistically significant $(p<0.001)$ for the complete core and also for the Anthropocene. The Fe/Ti profile shows short-time and low amplitude variability around a constant mean value, without any visible or statistically significant trend. The time evolution of the terrigenous elements $\mathrm{K}$ and $\mathrm{Ti}$, and the marker for biogenic origin $\mathrm{Sr}$, are represented in Figure 5. Since the onset of the Anthropocene, there is not statistical difference in the terrigenous content with time, while it is significant $(p<0.001)$ for the biogenic proxy Sr. 

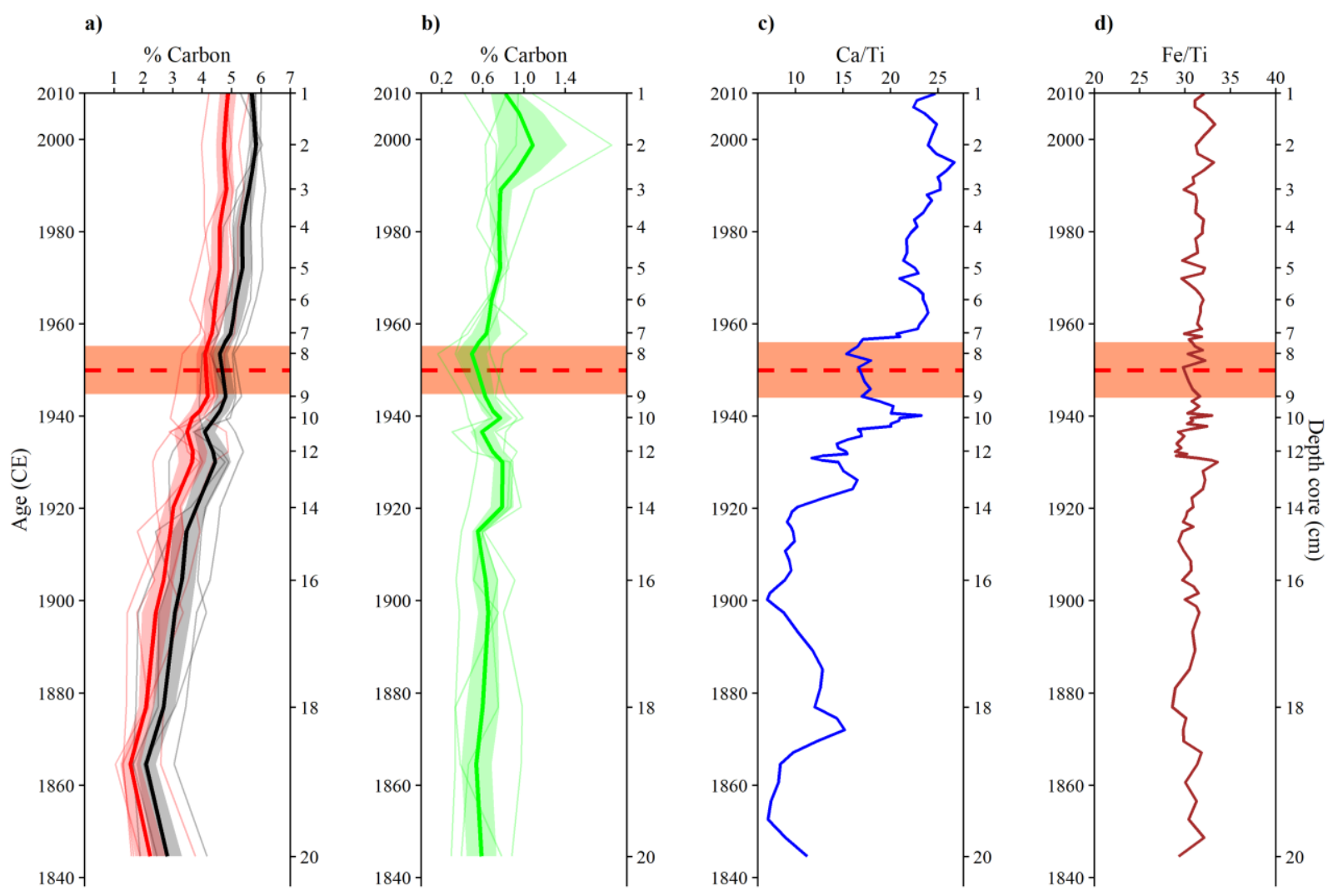

Figure 4. Time evolution of quantitative a) total (TC, black) and inorganic carbon (TIC, red) elemental composition and b) total organic carbon for the representative carbon profile of the central Irminger Basin. In both graphs, depicted in thin line at the same colors are the profiles for all the cores considered. Time evolution of semiquantitative elemental composition for $\mathrm{c}$ ) the ratio $\mathrm{Ca} / \mathrm{Ti}$; and $\mathrm{d}$ ) the ratio $\mathrm{Fe} / \mathrm{Ti}$ for the dated core. Dashed red line represents the onset of the Anthropocene at $1950 \mathrm{CE}$ along with the uncertainty in our dating at that time $( \pm 6 \mathrm{yr})$. The secondary $y$ axis at the left represent the depth of the core $(\mathrm{cm})$. 
a)

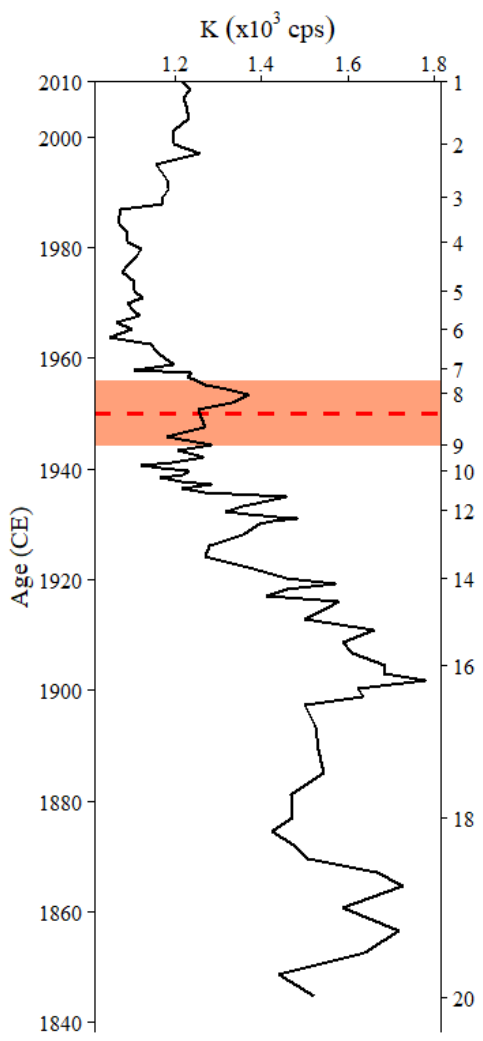

b)

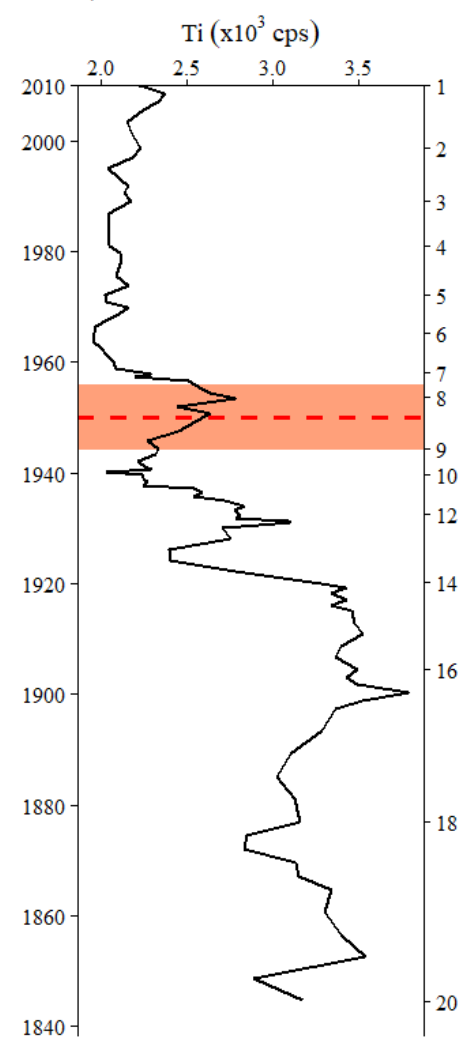

c)

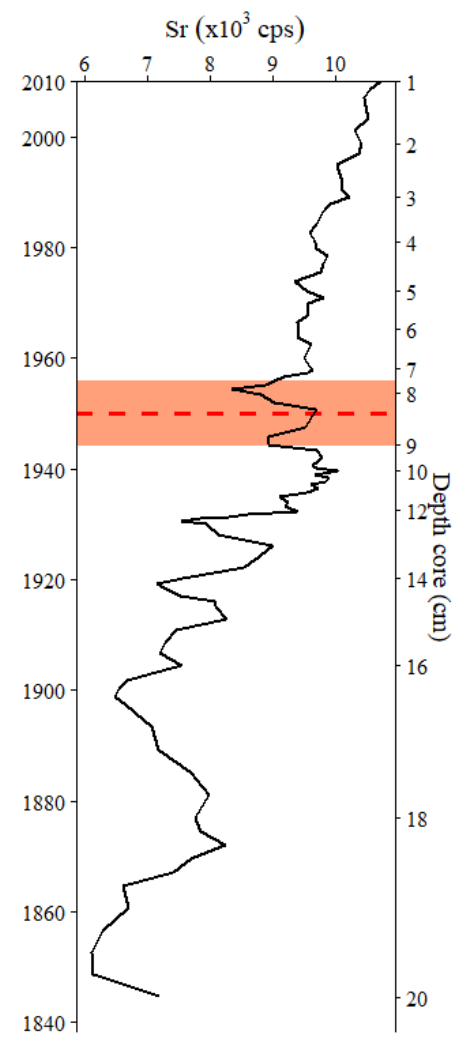

Figure 5. Time evolution of semi-quantitative elemental composition in the dated core for terrigenous elements a) $\mathrm{K}$; b) $\mathrm{Ti}$, and the marker for biogenic origin c) Sr. Dashed red line represents the limit of the Anthropocene, considered in the text at $1950 \mathrm{CE}$ along with the uncertainty in our dating at that time $( \pm 6 \mathrm{yr})$. The secondary $\mathrm{y}$ axis at the left represent the depth of the core $(\mathrm{cm})$.

\subsection{Carbon fluxes}

Following Eq.5, fluxes can be estimated for each element and each layer. The most determinant factor in the time evolution profile of mass flux is the mass accumulation rate (MAR): periods with greater MAR have higher fluxes. Taking into account that the aim of the study was to quantify recent sedimentary carbon fluxes, the results and discussion related with fluxes are limited to the temporal range from 1950 to the present, i. e., since the onset of the Anthropocene (Waters et al., 2016; Williams et al., 2016). During the Anthropocene, mean weighted flux to the sediment of inorganic and organic carbon in the central Irminger Basin are 4.6 $\pm 1.5 \mathrm{mg}-\mathrm{C}_{\text {inorg }} \cdot \mathrm{cm}^{-2} \cdot \mathrm{yr}^{-1}$ and $0.8 \pm 0.1 \mathrm{mg}-\mathrm{C}_{\text {org }} \cdot \mathrm{cm}^{-2} \cdot \mathrm{yr}^{-1}$ respectively. With an extension for the area deeper than $3000 \mathrm{~m}$ in the Irminger Basin of $1.6 \times 10^{4} \mathrm{~km}^{2}$ (ETOPO2 bathymetry), annual fluxes are $0.74 \pm 0.2 \mathrm{Tg}-\mathrm{C}_{\text {inorg }} \cdot \mathrm{yr}^{-1}, 0.13 \pm 0.02$ 
$357 \mathrm{Tg}-\mathrm{C}_{\text {org }} \cdot \mathrm{yr}^{-1}$, and $0.87 \pm 0.2 \mathrm{Tg}-\mathrm{C}_{\mathrm{T}} \cdot \mathrm{yr}^{-1}$. The Irminger Basin has a mean depth close to 2000 $358 \mathrm{~m}$ (ETOPO2 bathymetry). Taking into account that the downward flux attenuation is dependent of depth (Martin et al., 1987), we will expect that annual fluxes at basin-scale in the whole Irminger Basin will be higher.

\section{Discussion}

362 We are aware that the assumption of a shared geochronology for the cores of the central Irminger Basin deserves a tight justification. While there are numerous studies based on single proxy-based records of deep-sea sediment cores (Miettinen et al., 2011; Boessenkool et al; 2007; Hall et al, 2010, Mjell et al., 2016; Moffa-Sanchez et al., 2014), the results from a unique core might not be representative enough to infer Anthropocene carbon fluxes at basin-scale. However, we will argue how the integration of a representative carbon content profile makes sense. As noted before, there were several premises that were fulfilled in order to make the integration. Firstly, all the cores share the same sedimentary context (pelagic sediments, $>3000 \mathrm{~m}$ depth). Secondly, the grain-size characterization (Fig.2a) and the carbon content profiles (Fig.2b) show similar vertical distributions and trends between the independently sampled study sites. These facts are encouraging, despite the uncertainties, that the same chronology can be applied to the nearby cores of the central Irminger Basin. The acceptance of this assumption reinforces the main aim of the study: it allows to infer more realistic magnitudes of carbon buried in this wide area during the Anthropocene because the differences of ages between these nearby cores, if existent, are buffered. With regard to the geochronology, ${ }^{210} \mathrm{~Pb}$ excess specific activity profile (Fig. 2a) follows the radioactive decay law and does not show a perfect exponential signal, supporting the utilization of CRS model. The nonexistence of a homogenous layer of ${ }^{210} \mathrm{~Pb}$ excess activity suggests that in the dated core, no significant sediment mixing occurs (Oberle et al., 2016). These results show that a high efficiency and very low background gamma-ray spectrometry system (Quintana et al., 2017) is accurate and sensitive enough for dating high-resolution deep-sea pelagic sediments.

Some studies have reported ${ }^{210} \mathrm{~Pb}$ excess specific activities in surface sediments of deep water zones close to the central Irminger Basin. Boessenkool et al., (2007) measured surface concentrations of ${ }^{210} \mathrm{~Pb}_{\text {excess }}$ of $290 \mathrm{~Bq} \cdot \mathrm{kg}^{-1}$ by gamma spectrometry in sediments 
from the eastern flank of the Reykjanes Ridge collected at 2630 m water depth (black triangle in Fig. 1a). At a similar depth in the same location, Jonkers et al., (2010) reported activities from sediment and particles intercepted as high as $\sim 1000 \mathrm{~Bq} \cdot \mathrm{kg}^{-1}$ and 1500 $\mathrm{Bq} \cdot \mathrm{kg}^{-1}$ respectively. The superficial activity for ${ }^{210} \mathrm{Pbexcess}$ at the south of Greenland (3500 $\mathrm{m}$ water depth, white triangle in Fig. 1a) is around $360 \mathrm{~Bq} \cdot \mathrm{kg}^{-1}$ (Moffa-Sánchez et al., 2014). The range of values is quite large, with our data at the lower end. Some of these measures were done with gamma-spectrometry (Boessenkool et al., 2007; MoffaSánchez et al., 2014, the data showed here), while others were acquired with alphaspectrometry (Jonkers et al., 2010b). The ${ }^{210} \mathrm{~Pb}$ excess activities derived by alpha or gamma methods can be compared with confidence (Zaborska et al., 2007), so the measurement technique does not explain the differences observed between the superficial activities. The ${ }^{210} \mathrm{~Pb}$ excess activities at the sediment interface tend to increase with water depth due continuous scavenging by settling particles, however the depth distribution of the samples in our zone does not explain the differences. The more likely reason is that ${ }^{210} \mathrm{~Pb}$ excess activities in surface are closely related with superficial grain-size and TOC concentrations. In fact, the existence of a sub-superficial maximum of ${ }^{210} \mathrm{~Pb}$ excess located at $2 \mathrm{~cm}$ depth in the dated core (Fig. 3a) is in agreement with the TOC profile (Fig. 4b). A magnitude more interesting to compare than the superficial activity of ${ }^{210} \mathrm{~Pb}$ excess is the flux to the sediment surface $\left(\mathrm{Bq} \cdot \mathrm{m}^{-2} \cdot \mathrm{yr}^{-1}\right)$. This flux should be similar between cores and atmospheric fluxes in the same region (Masqué et al., 2002). Unfortunately, this magnitude is given only once for near sediments and with a value as high as $661 \mathrm{~Bq} \cdot \mathrm{m}^{-2} \cdot \mathrm{yr}^{-1}$ (Jonkers et al., 2010b). Our flux estimate $\left(29.9 \mathrm{~Bq} \cdot \mathrm{m}^{-2} \cdot \mathrm{yr}^{-1}\right)$ is notably minor, but it is in consonance with the atmospheric fallout values for sites remote from major land masses $\left(30-40 \mathrm{~Bq} \cdot \mathrm{m}^{-2} \cdot \mathrm{yr}^{-1}\right)$ (Appleby, 1998) and for the fluxes in the northeast Atlantic $\left(50 \mathrm{~Bq} \cdot \mathrm{m}^{-2} \cdot \mathrm{yr}^{-1}\right)($ Cochran, 1990; Thomson et al., 1993).

Artificial radionuclides ${ }^{137} \mathrm{Cs}$ and ${ }^{241} \mathrm{Am}$ are detectable in the environment after 1952 (Povinec et al., 2003). Since the decline of nuclear-bomb testing, nuclear accidents (Chernobyl 1986, Fukushima 2011) and intentional discharges from nuclear treatment plants (Sellafield, UK; Cape de la Hague, France) are the events of maximum inputs to the environment (Buesseler et al., 2011; Povinec et al., 2003). The detection of these radionuclides in deep-sea sediments is strongly dependent of a high-resolution 
measurement, because their concentration levels are close to counter detection limits (Harden et al., 1992). In fact, the activities reported for ${ }^{137} \mathrm{Cs}$ and ${ }^{241} \mathrm{Am}$ in the central Irminger Basin are among the lowest ones known in the literature. Furthermore, ${ }^{137} \mathrm{Cs}$ have post-depositional diagenetic mobility, limiting the resolution of specific dates (Sholkovitz and Mann, 1984). A downward migration process is proposed here as the cause for the detection of ${ }^{137} \mathrm{Cs}$ at 1920 and the non existence of sub-superficial peaks (Fig. 3b). The appearance of anthropogenic radionuclides in recent sediments is the result of the combination of fallout plus the incorporation from surrounding bottom waters. For this reason, the capabilities of a quantitative approach that shows clear correspondences between maximum peaks and CE dates are compromised. Nevertheless, here we show that the age model can be validated with anthropogenic radionuclides under presence/absence criteria because they appear approximately since the onset of the Anthropocene.

According with the CRS model, the MAR are relatively high in pelagic deep-sea environments. This implies that there is a sufficient supply of suspended particles that are scavenging ${ }^{210} \mathrm{~Pb}$ excess from the water column to be later deposited as fine-grained sediments at the bottom. The value found in the central Irminger Basin for sediment accumulation rate $\left(1.28 \pm 0.18 \mathrm{~mm} \cdot \mathrm{yr}^{-1}\right.$.) is greater than the estimate given at the south tip of Greenland in the Labrador Sea (white triangle in Fig. 1a) ( 0.4 mm. $\mathrm{rr}^{-1}$ ) (MoffaSánchez et al., 2014). The minor magnitude for the Moffa-Sánchez et al., (2014) core can be related with its deeper situation, near 3500 m water depth. Rates of sedimentation in the eastern flank of the Reykjanes Ridge (black triangle in Fig. 1a) estimated with the ${ }^{210} \mathrm{~Pb}$ dating, are around $2 \mathrm{~mm} \cdot \mathrm{yr}^{-1}$ (Boessenkool et al., 2007; Jonkers et al., 2010b). This higher magnitude is expected, since they are located in the Gardar Drift, a contourite deposit well-known by its high MAR (Bianchi and McCave, 2000).

One of the studies in the Gardar Drift gives the comparative between the accumulation flux determined with the ${ }^{210} \mathrm{~Pb}$ sediment dating and the flux intercepted with sediment traps (Jonkers et al., 2010b). Despite the uncertainties associated with its use (Buesseler et al., 2006), deep tethered sediment traps are a usual way to estimate the magnitude of the sedimentation flux into the deep ocean. Jonkers et al., (2010) gives values of 363 $\mathrm{g} \cdot \mathrm{m}^{-2} \cdot \mathrm{yr}^{-1}$ and $600 \mathrm{~g} \cdot \mathrm{m}^{-2} \cdot \mathrm{yr}^{-1}$ for the fluxes with sediment traps and from the sediment 
respectively. They are quite different, but in the same order of magnitude. Sediment focusing for high turbidity between the bottom and the depth of sediment trap (4 $\mathrm{m}$ above bottom), was suggested as a reason (Jonkers et al., 2010b).

Currently, in the Irminger Basin there is only one location with publicly available sediment trap data (Torres-Valdés et al., 2014). The mean total mass flux reported for all the episodic periods between 2003-2007 is $11.6 \mathrm{~g} \cdot \mathrm{m}^{-2} \cdot \mathrm{yr}^{-1}$ (Jonkers et al., 2010a), quite far from our estimate of $1192 \mathrm{~g} \cdot \mathrm{m}^{-2} \cdot \mathrm{yr}^{-1}$, and clearly not in the same order of magnitude. Even the largest episode of export, like the one occurred between May-June 2007 with almost $38 \mathrm{~g} \cdot \mathrm{m}^{-2} \cdot \mathrm{yr}^{-1}$ (Jonkers et al., 2010a), is still short. In fact, this value is close to the flux reported here for TC $\left(54 \mathrm{~g} \cdot \mathrm{m}^{-2} \cdot \mathrm{yr}^{-1}\right)$, without having into account the lithogenic mass flux. The distance between the bottom and the sediment trap in Jonkers et al. (2010b) was 250 meters, so deposition from nepheloid bottom layers can not be disregard as one of the causes of such discrepancies. Unfortunately, we have no info about turbidity, and moreover, it is a large difference, so more factors are needed to explain it.

Comparison with older times, the input of terrigenous elements decreased at the onset of the Anthropocene and is constant since in terms of composition, origin and transport agent, presumably aeolian deposition (Fig. 4d, Fig.5a-b). In contrast, the time-evolution of elemental composition shows that the biogenic component of the total mass flux (Fig. $4 a-c$, Fig. $5 c$ ) has increased since the $X X^{\text {th }}$ century. Despite relatively lower sedimentation rates during the last 25 years than during previous decades (Fig. 3c), it is very likely that biogenic inputs have increased in the most recent times. We suggest two processes to explain it: an increase in biological productivity that consequently increase the biogenic inputs at the bottom; or a decrease in the terrigenous input of material while the biogenic input remains unperturbed. The increase in productivity in recent times is supported by the biogenic proxies $\mathrm{Ca}$ and $\mathrm{Sr}$. The minor input of terrigenous material since the onset of the Anthropocene is supported by the $\mathrm{K}$ and Ti profiles. Very likely, a combination of both processes is the reason why biogenic inputs have gained strength in recent times. The increase in biogenic input is significant for both carbon fractions but more apparent in TIC than in TOC due its greater concentrations. These short time-scale changes observed in the sediment are probably related with atmospheric forcing and/or changes 
480 in the speed of the bottom overflow, as previously suggested (Boessenkool et al., 2007; 481 Hall et al., 2010; Mjell et al., 2016).

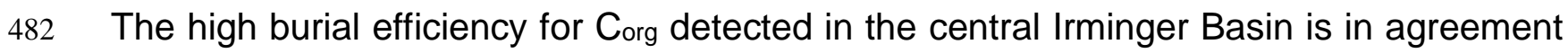
483 with the high MAR (Katsev \& Crowe, 2015), and discards the influence of significant post484 depositional diagenesis processes.

485 Combining the mass flux estimated by the ${ }^{210} \mathrm{~Pb}$ dated profile with the results of the 486 quantitative high-resolution carbon elemental composition representative of the central 487 Irminger Basin, mean Corg flux during the Anthropocene is $7 \pm 1 \mathrm{~g}-\mathrm{C}_{\text {org }} \cdot \mathrm{m}^{-2} \cdot \mathrm{yr}^{-1}$. According 488 to a global synthesis of modelled carbon fluxes to the open ocean, the flux of $\mathrm{C}_{\text {org }}$ at 2000 $\mathrm{m}$ in the Irminger Basin is between 0.5-1 mol-Corg $\mathrm{m}^{-2} \cdot \mathrm{yr}^{-1}$ (Honjo et al., 2008), i.e., around 6-12 $\mathrm{g}-\mathrm{C}_{\mathrm{org}} \cdot \mathrm{m}^{-2} \cdot \mathrm{yr}^{-1}$. From $2000 \mathrm{~m}$ to the bottom, remineralization processes will continue to diminish the organic carbon fraction in downward particles (Antia et al., 2001), so our fluxes of Corg coincide quite well with the lower-end of the range of Honjo et al. (2008). The flux of $C_{\text {inorg }}$ modelled in the Irminger in Honjo et al. (2008) is between 0.1-0.2 mol Cinorg $\cdot \mathrm{m}^{-2} \cdot \mathrm{yr}^{-1}$, five times smaller than the Corg fluxes. Despite that local peculiarity, they concluded that at large scale the molar ratio of $\mathrm{C}_{\text {org }} / \mathrm{C}_{\text {inorg }}$ is close to one. Here, given the increasing prevalence of carbonates along the cores (Fig. 4c), the assumption that all the flux of $\mathrm{C}_{\text {inorg }}$ is because of carbonates is feasible, so the molar ratio of $\mathrm{C}_{\text {org }} / \mathrm{C}_{\text {inorg }}$ since the Anthropocene is 0.17 . The molar ratio of $\mathrm{C}_{\mathrm{org}} / \mathrm{C}_{\text {inorg }}$ in particle flux for a time series sediment trap in the deep northeast Atlantic is 1.4 (Lampitt et al., 2010). That same value is found when the subpolar North Atlantic in a pan-Atlantic data compilation is analyzed (Torres Valdés et al., 2014). The reasons for such a low ratio can be multiple: important local variability in export production, the longer timescale integrated under our approach (multidecadal timescale), or the high TIC content in the measured cores due biogenic carbonate sedimentation (Fig. 4c) among others. Our $\mathrm{C}_{\text {org }} / \mathrm{C}_{\text {inorg }}$ ratios were obtained under a different approach that Honjo et al. (2008) or Lampitt et al. (2010), but the results suggest that an important biogeochemical process alters significantly the ratios preserved at the sediment. The closest layer of water near-seafloor, the benthic nepheloid layer (BNL), is characterized by an enhanced biological activity (Townsend et al., 1992). The thickness of the BNL in the central Irminger Basin is around $50 \mathrm{~m}$ (Gardner et al., 2018). Neither with sediment traps located outside the BNL or with surface sediments analysis 
511 would be detected a hypothetical transformation of organic into inorganic carbon

512 mediated by the heterotrophic community of that layer. This biogeochemical process 513 would affect the carbon fraction distributions, and it would represent an underestimation

514 (overestimation) in the organic (inorganic) carbon fraction that is incorporated in the 515 sediment. Therefore, organic carbon cycling in the uppermost centimeters of the seafloor 516 can be the reason why the $\mathrm{C}_{\text {org }} / \mathrm{C}_{\text {inorg }}$ molar ratio of settlement equal to one is displaced 517 to molar ratios $\sim 1: 6$ in the final configuration of the sediment.

\section{Conclusions}

The chronological framework based in ${ }^{210} \mathrm{~Pb}$ dating reveals that in the central and deepest areas of Irminger Basin, the Anthropocene represents the firsts $8 \mathrm{~cm}$ of sediment and the average sedimentation rate is $1.28 \pm 0.18 \mathrm{~mm} \cdot \mathrm{yr}^{-1}$, quite high for a deep-sea basin. Inter-annual variability in the sedimentation rate and in the terrigenous and biogenic proxies suggests short time-scale changes of bottom currents and/or biological productivity at the central Irminger Basin during the Anthropocene. The latest 50 years show an enhanced biological productivity along with a decrease in the aeolian input of terrigenous material.

With the geochemical characterization of the deepest area of the basin ( $>3000 \mathrm{~m}$ ), we conclude that since the onset of the Anthropocene $46 \pm 15 \mathrm{~g}-\mathrm{C}_{\text {inorg }} \cdot \mathrm{m}^{-2} \cdot \mathrm{yr}^{-1}$ and $8 \pm 1 \mathrm{~g}$ Corg $\cdot \mathrm{m}^{-2} \cdot \mathrm{yr}^{-1}$ have been buried in the central Irminger Basin, generating a substantial carbon sink in the area of at least $1 \mathrm{Tg}-\mathrm{C} \cdot \mathrm{yr}^{-1}$. It is reasonable to think that shallower areas of the basin would contribute at least equal or, probably even more to the carbon sedimentation, so this outcome has to be accounted for in current ocean carbon models and budgets. It is too soon to infer any reliable trend in the flux of carbon since 1950, but the current status of knowledge would act as a baseline in future evaluations of carbon cycle in deep marine sediments of the North Atlantic.

\section{Acknowledgments}

The authors are grateful to the Captain, crew, technicians and scientists aboard the R/V Sarmiento de Gamboa, for their support during the cruise BOCATS/OVIDE 2016. We thank all who contributed to the acquisition and data analysis during the laboratory analysis. We thank the Editor, Fabienne Marret-Davies, and two anonymous reviewers for their constructive and useful comments in order to improve this paper. For this work M. Fontela was funded by the Spanish Ministry of Economy and Competitiveness (BES- 
2014-070449) through the BOCATS project (CTM2013-41048-P) supported by the Spanish Government and co-funded by the Fondo Europeo de Desarrollo Regional 20072012 (FEDER). M.J. Álvarez-Fernandez and F.F. Pérez were supported by the BOCATS project (CTM2013-41048-P) co-funded by the Spanish Government and the Fondo Europeo de Desarrollo Regional (FEDER). I. Alejo, M.A. Nombela and G.Francés were supported by the BOCATS project (CTM2013-41048-P) and the University of Vigo. B. Quintana and M.C. Pedrosa were supported by University of Salamanca. The authors declare no competing financial interests.

\section{Data availability}

All the data used on this study is available in the figures, supplementary information and references

\section{References}

Álvarez-Vázquez, M.Á., Caetano, M., Álvarez-Iglesias, P., Pedrosa-García, M. del C., Calvo, S., De Uña-Álvarez, E., Quintana, B., Vale, C., Prego, R., 2016. Natural and Anthropocene fluxes of trace elements in estuarine sediments of Galician Rias. Estuar. Coast. Shelf Sci. doi:10.1016/j.ecss.2016.08.022

Antia, N., Peinert, R., Hebbeln, D., Bathmann, U., Fehner, U., Zeitzschel, B., 2001. Basin-wide particulate carbon flux in the Atlantic Ocean ' Regional export patterns and potential for atmospheric sequestration Avan Detlef TM Jan s Susanne regional differences in changes of the export ratio with depth are related to over the Atlantic Oc. Global Biogeochem. Cycles 15, 845-862. doi:10.1029/2000gb001376

Appleby, P.G., 1998. Dating recent sediments by $210 \mathrm{~Pb}$ : problems and solutions. Stuk a-145 7-24.

Appleby, P.G., Oldfield, F., 1983. The assessment of ${ }^{210} \mathrm{~Pb}$ data from sites with varying sediment accumulation rates. Hydrobiologia 103, 29-35. doi:10.1007/BF00028424

Bianchi, G.G., McCave, I.N., 2000. Hydrography and sedimentation under the deep western boundary current on Bjorn and Gardar Drifts, Iceland Basin. Mar. Geol. 165, 137-169. doi:10.1016/S0025-3227(99)00139-5

Boessenkool, K.P., Hall, I.R., Elderfield, H., Yashayaev, I., 2007. North Atlantic climate and deep-ocean flow speed changes during the last 230 years. Geophys. Res. Lett. 34, 2-7. doi:10.1029/2007GL030285 
Buesseler, K., Aoyama, M., Fukasawa, M., 2011. Impacts of the Fukushima nuclear power plants on marine radioactivity. Environ. Sci. Technol. 45, 9931-9935. doi:10.1021/es202816c

Buesseler, K.O., Benitez-Nelson, C.R., Moran, S.B., Burd, A., Charette, M., Cochran, J.K., Coppola, L., Fisher, N.S., Fowler, S.W., Gardner, W.D., Guo, L.D., Gustafsson, Ö., Lamborg, C., Masque, P., Miquel, J.C., Passow, U., Santschi, P.H., Savoye, N., Stewart, G., Trull, T., 2006. An assessment of particulate organic carbon to thorium-234 ratios in the ocean and their impact on the application of 234Th as a POC flux proxy. Mar. Chem. 100, 213-233. doi:10.1016/j.marchem.2005.10.013

Burd, A.B., Hansell, D.A., Steinberg, D.K., Anderson, T.R., Arístegui, J., Baltar, F., Beaupré, S.R., Buesseler, K.O., DeHairs, F., Jackson, G.A., Kadko, D.C., Koppelmann, R., Lampitt, R.S., Nagata, T., Reinthaler, T., Robinson, C., Robison, B.H., Tamburini, C., Tanaka, T., 2010. Assessing the apparent imbalance between geochemical and biochemical indicators of meso- and bathypelagic biological activity: What the @\$\#! is wrong with present calculations of carbon budgets? Deep. Res. Part II Top. Stud. Oceanogr. 57, 1557-1571. doi:10.1016/j.dsr2.2010.02.022

Cochran, J.K., 1990. 210Pb scavenging in the North Atlantic and North Pacific Oceans. Earth Planet. Sci. Lett. 97, 332-352.

Crutzen, P.J., Stoermer, E.F., 2000. The Anthropocene. Glob. Chang. Newsl. 41, 1718.

de Jong, M.F., de Steur, L., 2016. Strong winter cooling over the Irminger Sea in winter 2014???2015, exceptional deep convection, and the emergence of anomalously low SST. Geophys. Res. Lett. 43, 7106-7113. doi:10.1002/2016GL069596

Frigola, J., Canals, M., Mata, P., 2015. Techniques for the non-destructive and continuous analysis of sediment cores. Application in the lberian continental margin. Boletín Geológico y Min. 
Harden, S.L., DeMaster, D.J., Nittrouer, C.A., 1992. Developing sediment geochronologies for high-latitude continental shelf deposits: a radiochemical approach. Mar. Geol. 103, 69-97. doi:10.1016/0025-3227(92)90009-7

Heinze, C., Meyer, S., Goris, N., Anderson, L., Steinfeldt, R., Chang, N., Le Qu??r??, C., Bakker, D.C.E., 2015. The ocean carbon sink - Impacts, vulnerabilities and challenges. Earth Syst. Dyn. 6, 327-358. doi:10.5194/esd-6-327-2015

Henson, S.A., Robinson, I., Allen, J.T., Waniek, J.J., 2006. Effect of meteorological conditions on interannual variability in timing and magnitude of the spring bloom in the Irminger Basin, North Atlantic. Deep. Res. Part I Oceanogr. Res. Pap. 53, 1601-1615. doi:10.1016/j.dsr.2006.07.009

Honjo, S., Manganini, S.J., Krishfield, R.A., Francois, R., 2008. Particulate organic carbon fluxes to the ocean interior and factors controlling the biological pump: A synthesis of global sediment trap programs since 1983. Prog. Oceanogr. 76, 217285. doi:10.1016/j.pocean.2007.11.003

Jonkers, L., Brummer, G.J.A., Peeters, F.J.C., Van Aken, H.M., De Jong, M.F., 2010a. Seasonal stratification, shell flux, and oxygen isotope dynamics of leftcoiling $\mathrm{N}$. pachyderma and T. quinqueloba in the western subpolar North Atlantic. Paleoceanography 25, 1-13. doi:10.1029/2009PA001849

Jonkers, L., Mienis, F., Boer, W., Hall, I.R., Brummer, G.J.A., 2010b. Intra-annual variability of extremely rapid sedimentation onto Gardar Drift in the northern North Atlantic. Deep. Res. Part I Oceanogr. Res. Pap. 57, 1027-1038. doi:10.1016/j.dsr.2010.05.005

Krishnaswamy, S., Lal, D., Martin, J.M., Meybeck, M., 1971. Geochronology of lake sediments. Earth Planet. Sci. Lett. 11, 407-414. doi:10.1016/0012-821X(71)902020

Lampitt, R.S., Salter, I., de Cuevas, B.A., Hartman, S., Larkin, K.E., Pebody, C.A., 2010. Long-term variability of downward particle flux in the deep northeast Atlantic: Causes and trends. Deep. Res. Part II Top. Stud. Oceanogr. 57, 1346-1361. 
Landschützer, P., Gruber, N., Bakker, D.C.E., 2016. Decadal variations and trends of the global ocean carbon sink. doi:10.1002/2015GB005359. Received

Mabit, L., Benmansour, M., Abril, J.M., Walling, D.E., Meusburger, K., lurian, A.R., Bernard, C., Tarján, S., Owens, P.N., Blake, W.H., Alewell, C., 2014. Fallout 210Pb as a soil and sediment tracer in catchment sediment budget investigations: $\mathrm{A}$ review. Earth-Science Rev. 138, 335-351. doi:10.1016/j.earscirev.2014.06.007

Masqué, P., Isla, E., Sanchez-Cabeza, J.A., Palanques, A., Bruach, J.M., Puig, P., Guillén, J., 2002. Sediment accumulation rates and carbon fluxes to bottom sediments at the western Bransfield Strait (Antarctica). Deep. Res. Part II Top. Stud. Oceanogr. 49, 921-933. doi:10.1016/S0967-0645(01)00131-X

Moffa-Sánchez, P., Hall, I.. I.R., Barker, S., Thornalley, D.J.R.D.J.., Yashayaev, I., 2014. Surface changes in the eastern Labrador Sea around the onset of the Little Ice Age. Paleoceanography 29, 160-175. doi:10.1002/2013PA002523.Received

Moore, W.S., Dymondt, J., 1988. Correlation of 210Pb removal with organic carbon fluxes in the Pacific Ocean. Nature 331, 339-341. doi:10.1038/331339a0

Oberle, F.K.J., Swarzenski, P.W., Reddy, C.M., Nelson, R.K., Baasch, B., Hanebuth, T.J.J., 2016. Deciphering the lithological consequences of bottom trawling to sedimentary habitats on the shelf. J. Mar. Syst. 159, 120-131. doi:10.1016/j.jmarsys.2015.12.008

Piron, A., Thierry, V., Mercier, H., Caniaux, G., 2017. Gyre-scale deep convection in the subpolar North Atlantic Ocean during winter 2014???2015. Geophys. Res. Lett. 44, 1439-1447. doi:10.1002/2016GL071895

Povinec, P.P., Bailly Du Bois, P., Kershaw, P.J., Nies, H., Scotto, P., 2003. Temporal and spatial trends in the distribution of $137 \mathrm{Cs}$ in surface waters of Northern European Seas - A record of 40 years of investigations. Deep. Res. Part II Top. Stud. Oceanogr. 50, 2785-2801. doi:10.1016/S0967-0645(03)00148-6 
Quintana, B., Fernández, F., 1998. Continuous component determination in y-ray spectra. Nucl. Instruments Methods Phys. Res. Sect. A Accel. Spectrometers, Detect. Assoc. Equip. 411, 475-493. doi:10.1016/S0168-9002(98)00334-9

Rothwell, R.G., Croudace, I. w., 2015. Micro-XRF Studies of Sediment Cores: A Perspective on Capability and Application in the Environmental Sciences, in: Croudace, I.W., Rothwell, R.G. (Eds.), Micro-XRF Studies of Sediment Cores: Applications of a Non-Destructive Tool for the Environmental Sciences. Springer Netherlands, Dordrecht, pp. 1-21. doi:10.1007/978-94-017-9849-5_1

Sanchez-Cabeza, J.A., Ani-Ragolta, I., Masquè, P., 2000. Some considerations of the $210 \mathrm{~Pb}$ constant rate of supply (CRS) dating model. Limnol. Oceanogr. 45, 990995. doi:10.4319/lo.2000.45.4.0990

Sanchez-Cabeza, J.A., Ruiz-Fernández, A.C., 2012. 210Pb sediment radiochronology: An integrated formulation and classification of dating models. Geochim. Cosmochim. Acta 82, 183-200. doi:10.1016/j.gca.2010.12.024

Sholkovitz, E.R., Mann, D.R., 1984. The pore water chemistry of Pu-239,-240 and Cs137 in sediments of Buzzards Bay, Massachusetts. Geochim. Cosmochim. Acta 48, $1107-1114$.

Steffen, W., Grinevald, J., Crutzen, P., McNeill, J., 2011. The Anthropocene: conceptual and historical perspectives. Philos. Trans. R. Soc. A Math. Phys. Eng. Sci. 369, 842-867. doi:10.1098/rsta.2010.0327

Steffen, W., Leinfelder, R., Zalasiewicz, J., Waters, C.N., Williams, M., Summerhayes, C., Barnosky, A.D., Cearreta, A., Crutzen, P., Edgeworth, M., Ellis, E.C., Fairchild, I.J., Galuszka, A., Grinevald, J., Haywood, A., Ivar do Sul, J., Jeandel, C., McNeill, J.R., Odada, E., Oreskes, N., Revkin, A., Richter, D. de B., Syvitski, J., Vidas, D., Wagreich, M., Wing, S.L., Wolfe, A.P., Schellnhuber, H.J., 2016. Stratigraphic and Earth System approaches to defining the Anthropocene. Earth's Futur. doi:10.1002/2016EF000379

Takahashi, T., Sutherland, S.C., Wanninkhof, R., Sweeney, C., Feely, R.A., Chipman, 
D.W., Hales, B., Friederich, G., Chavez, F., Sabine, C., Watson, A., Bakker, D.C.E., Schuster, U., Metzl, N., Yoshikawa-Inoue, H., Ishii, M., Midorikawa, T., Nojiri, Y., Körtzinger, A., Steinhoff, T., Hoppema, M., Olafsson, J., Arnarson, T.S., Tilbrook, B., Johannessen, T., Olsen, A., Bellerby, R., Wong, C.S., Delille, B., Bates, N.R., de Baar, H.J.W., 2009. Climatological mean and decadal change in surface ocean pCO2, and net sea-air CO2 flux over the global oceans. Deep. Res. Part II Top. Stud. Oceanogr. 56, 554-577. doi:10.1016/j.dsr2.2008.12.009

Thomson, J., Colley, S., Anderson, R., Cook, G.T., MacKenzie, A.B., 1993. 210Pb in the sediments and water column of the Northeast Atlantic from 47 to $59^{\circ} \mathrm{N}$ along 20W. Earth Planet. Sci. Lett. 115, 75-87. doi:10.1016/0012-821X(93)90214-T

Torres-Valdés, S., Painter, S.C., Martin, A.P., Sanders, R., Felden, J., 2014. Data compilation of fluxes of sedimenting material from sediment traps in the Atlantic ocean. Earth Syst. Sci. Data 6, 123-145. doi:10.5194/essd-6-123-2014

Torres Valdés, S., Painter, S.C., Martin, A.P., Sanders, R., Felden, J., 2014. Data compilation of fluxes of sedimenting material from sediment traps in the Atlantic ocean. Earth Syst. Sci. Data 6, 123-145. doi:10.5194/essd-6-123-2014

Våge, K., Pickart, R.S., Sarafanov, A., Knutsen, Ø., Mercier, H., Lherminier, P., van Aken, H.M., Meincke, J., Quadfasel, D., Bacon, S., 2011. The Irminger Gyre: Circulation, convection, and interannual variability. Deep. Res. Part I Oceanogr. Res. Pap. 58, 590-614. doi:10.1016/j.dsr.2011.03.001

Waters, C.N., Zalasiewicz, J., Summerhayes, C., Barnosky, A.D., Poirier, C., Ga uszka, A., Cearreta, A., Edgeworth, M., Ellis, E.C., Ellis, M., Jeandel, C., Leinfelder, R., McNeill, J.R., Richter, D. d., Steffen, W., Syvitski, J., Vidas, D., Wagreich, M., Williams, M., Zhisheng, A., Grinevald, J., Odada, E., Oreskes, N., Wolfe, A.P., 2016. The Anthropocene is functionally and stratigraphically distinct from the Holocene. Science (80-. ). 351, aad2622-aad2622. doi:10.1126/science.aad2622

Williams, M., Zalasiewicz, J., Waters, C.N., Edgeworth, M., Bennett, C., Barnosky, A.D., Ellis, E.C., Ellis, M.A., Cearreta, A., Haff, P.K., Ivar Do Sul, J.A., Leinfelder, R., 
McNeill, J.R., Odada, E., Oreskes, N., Revkin, A., Richter, D.D.B., Steffen, W., Summerhayes, C., Syvitski, J.P., Vidas, D., Wagreich, M., Wing, S.L., Wolfe, A.P., Zhisheng, A., 2016. The Anthropocene: A conspicuous stratigraphical signal of anthropogenic changes in production and consumption across the biosphere. Earth's Futur. 4, 34-53. doi:10.1002/2015EF000339

Zaborska, A., Carroll, J.L., Papucci, C., Pempkowiak, J., 2007. Intercomparison of alpha and gamma spectrometry techniques used in $210 \mathrm{~Pb}$ geochronology. J. Environ. Radioact. 93, 38-50. doi:10.1016/j.jenvrad.2006.11.007 